\title{
Role of Stem Cells in Management of Experimentally Induced Hypothyroidism in Albino Rat
}

\author{
SHADIA E. EL NABARAWY, M.D.; OLFAT A. ABD-EL-ATY, M.D.; MONA A.A. ARAFA, M.D. and \\ RASHA K. ELSAID, M.Sc.
}

The Department Anatomy, Faculty of Medicine for Girls, Al-Azhar University, Cairo, Egypt

\begin{abstract}
Background: Hypothyroidism is a common condition with potentially devastating health consequences that spread worldwide. Stems cells (SCs) based therapy had showed promising benefits in treatment of many diseases on animal models and applied on some human clinical issues.
\end{abstract}

Aim of Study: To investigate the effect of bone marrow mesenchymal stem cells (BM-MSCs) on the biochemical and histological structures of the thyroid gland after experimentally induced hypothyroidism in adult male albino rats.

Material and Methods: Forty five adult male SpragueDawley albino rats were divided into 3 equal groups: Control group (Group I), Hypothyroidism induced group (Group II); received orally carbimazole $45 \mathrm{mg} / \mathrm{kg}$ of rat/day for 5 days/week for 4 weeks and Induced hypothyroidism treated with BMMSCs group (Group III); received oral dose of carbimazole $45 \mathrm{mg} / \mathrm{kg}$ of rat/day for 5 days/week for 4 weeks then received single intravenous injection of $1 \times 10$ cells of BM-MSCs. This group was subdivided into three equal subgroups according to the time of scarification; Subgroup III6: Scarified at the end of 6 th week, Subgroup III8: Scarified at the end of $8^{\text {th }}$ week and Subgroup III10: Scarified at the end of 10 th week. At the end of the experiment, the hormones of thyroid function were measured and histological examination of the thyroid tissue were done. In addition to morphometric study and statistical analysis.

Results: BM-MSCs injection to the induced hypothyroidism rats showed that after 6 and 8 weeks, there were highly significant increase $(p<0.01)$ of freeT3 and T4 values and highly significance decrease of TSH compared to the induced hypothyroidism group. On the other hand, after 10 weeks from injection of BM-MSCs, there were insignificant differences $(p>0.05)$ of free T3, T4 and TSH compared to the induced hypothyroidism group. The histological examination of the induced hypothyroidism after 6 weeks of BM-MSCs injection showed variable degree of response. However, after 8 weeks of BM-MSCs injection, there was universal improve-

Correspondence to: Dr. Shadia E. El Nabarawy, The Department Anatomy, Faculty of Medicine for Girls, Al-Azhar University, Cairo, Egypt ment of all examined fields that confirmed statistically by improvement of the heights of follicular cells, area percent of collagen fibers and area percent of colloid. On the other hand, after 10 weeks of BM-MSCs injection, there was marked regression in response to SCs treatment in all examined parameters.

Conclusion: BM-MSCs injection almost restored the function and histological structures of the thyroid gland after 8 weeks. However, this improvement was declined after 10 weeks of BM-MSCs injection. So second dose is recommended.

Key Words: Albino rats - Thyroid gland - Induced hypothyroidism-BM-MSCs.

\section{Introduction}

HYPOTHYROIDISM is a hypometabolic clinical state resulting from inadequate production of thyroid hormones for prolonged periods, or rarely, from the resistance of the peripheral tissues to the effects of thyroid hormones [1]. Carbimazole is an antithyroid medication, generally used to treat Graves' disease. Carbimazole was a prodrug of the active structure methimazole which kept the thyroid peroxidase enzyme from coupling and iodinating the tyrosine deposited on thyroglobulin, consequently decreasing the generation of $\mathrm{T} 3$ and $\mathrm{T} 4$. Over a period of time, the inhibition of hormone synthesis resulted in the depletion of stores of iodinated thyroglobulin [2]. The stem cells (SCs) are undifferentiated cells that can differentiate into specialized cells and could divide (through mitosis) to produce more SCs. They are present in multicellular organism. There are three types of SCs: embryonic (ESCs), fetal (FSCs) and adult (ASCs) [3]. ASCs refers to any cell which is found in a developed organism that has two properties; the ability to divide and create another cell like itself and the ability to divide and create a cell more 
differentiated than itself [4]. ASCs is commonly used in cell based therapy because of their ability to divide or selfrenew indefinitely, and it can generate all the cell types of the organ from which they originate. Unlike for ESCs, the use of human ASCs in research and therapy is not considered to be controversial, as they are derived from adult tissue samples rather than human embryos. It can be easily obtained in large amounts from patient's own tissue (especially bone marrow and fat) and present an extremely low risk of tumorigenesis [ $\mathbf{r}$ Mesenchymal stem cells (MSCs) are special type of ASCs. MSCs have the potential to differentiate in vitro and in vivo into multiple lineages including adipogenic, chondrogenic and osteogenic. In addition, MSCs have the capability to self-renew in order to maintain their undifferentiated state. Regardless of their tissue of origin, MSCs are characterized by the presence or absence of certain markers [6]. MSCs are used in treatment of Parkinson's disease and muscular dystrophies. These cells also have been used for treatment of diabetes and its complications. These cells were used in the management of infertility (both male and female) [7]. Bone marrow mesenchymal stem cells (BMMSCs) are cellular component of the bone marrow stroma which contains a heterogeneous population of cells that, as a whole, contributed to hematopoiesis. It includes adipocytes, reticular cells, macrophages, vascular endothelial cells, smooth muscle cells and MSCs [8]

This work aims to investigate the effect of BMMSCs on the biochemical and histological structures of thyroid gland after experimentally induced hypothyroidism in adult male albino rats.

\section{Patients and Methods}

This work was conducted from 9/2016 to 9/2018 at animal house of Faculty of Medicine for Girls, Al-Azhar University, Egypt.

\section{A- Experiment:}

Forty five adult male Sprague-Dawley albino rats weighting about 250-3 00 $\pm 50 \mathrm{gm}$ were used. The rats were purchased from the Egyptian Organization for Biological Products and Vaccines (Cairo, Egypt). The animals were kept in the animal house of Faculty of Medicine for Girls Al-Azhar University (Cairo, Egypt). They were housed in stainless steel cages $(27 \mathrm{X} 38 \mathrm{X} 17 \mathrm{~cm})$ at $21^{\circ} \mathrm{C}-24^{\circ} \mathrm{C}$ and acclimatized in a $12 \mathrm{~h} \mathrm{light/dark} \mathrm{cycle.} \mathrm{They} \mathrm{were}$ allowed for laboratory rat chow diet and water. Strict care and hygiene were taken to maintain normal and healthy environment for all rats all time. The study followed the International Society of Applied Ethology (ISAE) guidelines concerning animal rights. The rats were divided into three equal groups of 15 rats/each as following:

Group I: Control group:Without receiving anything.

Group II: Hypothyroidism induced group: Each rat received oral dose of carbimazole $45 \mathrm{mg} / \mathrm{kg}$ of rat/day for 5 days/week for 4 weeks.

Group III: Induced hypothyroidism treated with BM-MSCs group: Each rat received oral dose of carbimazole $45 \mathrm{mg} / \mathrm{kg}$ of rat/day for 5 days/week for 4 weeks then received single intravenous injection of $1 \mathrm{x} 106$ cells of BM-MSCs suspended in $1 \mathrm{ml}$ of phosphate buffered saline and nutritive serum in the tail vein. This group was subdivided into three equal subgroups according to time of scarification after BM-MSCs injection: Subgroup III6: Scarified at the end of $6^{\text {th }}$ week. Subgroup III8: Scarified at the end of 8 th week. Subgroup III10: Scarified at the end of $10^{\text {th }}$ week.

\section{B- Drugs:}

1- Carbimazole is an antithyroid medication, generally used to treat Graves' disease. It is produced by Chemical Industries Development (CID) in the form of white, crystalline tablet that is freely soluble in water. Each tablet contains $5 \mathrm{mg}$ (43.8 methimazole [9]. The dose used in this study was $45 \mathrm{mg} / \mathrm{kg}$ of rat/day for 5 days/week for 4 weeks via gastric gavage tube according to Europa et al. (2010) [10].

2- BM-MSCs were isolated from 10 albino rats 6-8 weeks old. The animal was put into an anesthesia chamber. Skin incisions in the lateral aspect of the thigh were done then the femurs and tibias from the hind limbs were cut off after removal of tendons and muscles. The dissected femurs and tibias were put in $70 \%$ isopropanol for a few seconds then transfered to Phosphate buffer saline (PBS). In a biosafety cabinet, the femurs and tibias were transferred to a $10 \mathrm{~cm}$ dish containing Dulbecco's modified Eagle's medium (DMEM). Each bone was then held with tweezers and the two ends were cut open with a scissor. A22G needle attached to a $3 \mathrm{ml}$ syringe and filled with DMEM. The bone marrow was harvested by flushing the tibiae and femurs with DMEM supplemented with $10 \%$ Fetal bovine serum (FBS). The bone marrow was harvested in heparinized conical tubes. Under aseptic conditions for all cases, the harvested bone marrow cells were gently pipetted to break up cell clumps, the cells were centrifuged at $2000 \mathrm{rpm}$ for $20 \mathrm{~min}$, 
then the cell pellet was resuspended carefully onto $5 \mathrm{ml}$ of $60 \%$ Ficoll Hypaque separating solution (Ficoll/Paque (Pharmacia)) in sterile conical tube, and then centrifuged for $20-25 \mathrm{~min}$ at $2000 \mathrm{rpm}$ at $8^{\circ} \mathrm{C}$. The mononuclear cells were retrieved from the buffy coat layer by sterile Pasteur pipette and placed in $5 \mathrm{ml}$ sterile conical tube. The cells were washed two to three times with PBS and centrifuged at $2000 \mathrm{rpm}$ for $20 \mathrm{~min}$. Cells were counted using automated cell counter (Cell Dyne, Inc, USA). The nucleated cells were resuspended in complete culture medium supplemented with $1 \%$ penicillinstreptomycin. The cell suspension was seeded in three T25 tissue culture flasks, in a density of 100.000 cells in each flask, with $5 \mathrm{ml}$ culture medium. Then the cells were incubated at $37^{\circ} \mathrm{C}$ in humidified atmosphere of 5\% $\mathrm{CO} 2$ for 12-14 days as primary culture or upon formation of large colonies. When large colonies developed (80-90\% confluence), cultures were washed twice with PBS. To remove the none-adherent cells, the cultures were inspected daily for the formation of adherent spindle shaped fibroblast cell colonies. The subculturing was carried out by $0.25 \%$ trypsin in $1 \mathrm{ml}$ EDTA for $5 \mathrm{~min}$ at $37^{\circ} \mathrm{C}$. After centrifugation, cells were resuspended with serum-supplemented medium and incubated in $50 \mathrm{~cm}^{2}$ culture flask (Falcon). The resulting cultures were referred to as firstpassage cultures. On day 14 , the adherent colonies of cells were trypsinized, and counted $[11,12]$. For identification of BM-MSCs, Flow cytometric analyses were carried out on fluorescence activated cell sorter flow cytometer. The cell surface molecules analysis was performed to verify the surface marker expressions. The cells were detached from culture dish with Trypsin/EDTA and counted. About $2 \times 10^{5}$ cells of BM-MSCs were divided into three aliquots in amber-tinted $5 \mathrm{ml}$ centrifuge tubes and $3 \%$ rat serum was added. The cells were incubated on ice for 30 minutes, resuspended in 400 JPES and pelleted by centrifugation for 10 minutes at 400Xg [13]. After that the cells were stained with three fluorescent markers for 1 hour at $4^{\circ} \mathrm{C}$; antiCD29 (mesenchymal stem cell-specific marker; Biolegend- USA), anti-CD90 (mesenchymal stem cell-specific marker; Biolegend, San Diego, CA) and isothiocyanate-conjugated rat antimouse CD34 (BD Pharmingen, Franklin Lakes, NJ, USA). After washing with PBS, the cells were resuspended in $0.5 \mathrm{ml}$ stain buffer (BD- Pharmingen) for flow cytometric analysis [14]. The cells showed positive staining against MSC markers CD29 (Fig. A) and CD90 (Fig. B) but negative against CD34 (Fig. C). This indicated that the enrichment of the cells was good for rat MSCs.
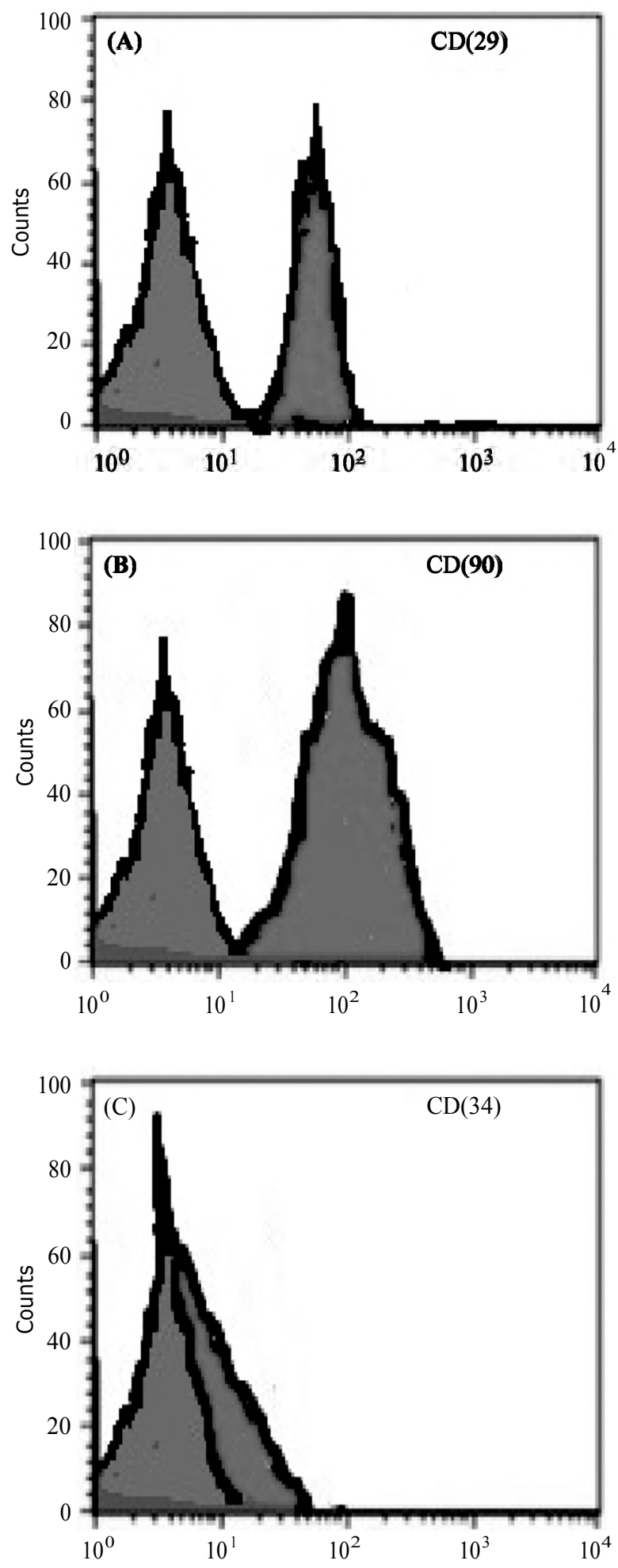

Figs. (A,B,C): Photographs of flow cytometer analysis to verify the markers of MSCs.

\section{C- Collection of the specimens and preparation for examination:}

At the end of the experiment, the animals were anesthetized by ether to avoid the effect of stress of manipulation on hormonal levels; blood was 
collected through the retro-ocular puncture. Then all studied animals were dissected, the skin at the midline was pulled up and cut forward to the level of lower lips by using a forceps and a pointed scissor. The skin is then separated from the underlying muscle by pulling it gently by using a forceps and a blunt probe, the ventral side of neck is clearly exposed. The right and left sternomastoid form a ' $\mathrm{V}$ ' shape at the base of the neck. After identification of the muscles, retraction of the muscle was done to expose the underlying trachea. The thyroid gland is located immediately caudal to the larynx on either side of the trachea. Once the trachea is exposed, it needs to be traced upwards gently until the thyroid gland is visible. The thyroid gland usually appears as two small reddish oval masses, one on each side of the trachea but the isthmus is barely visible. The thyroid glands were excised and prepared for histological studies by light microscope.

1- Hormonal assay: The blood Samples were left to clot for $20 \mathrm{~min}$ and centrifuged at 3000 (rpm) for $20 \mathrm{~min}$ then the separated serum was kept frozen at $20^{\circ} \mathrm{C}$ till analysis of thyroid function test. Assessment of levels of T3, T4 and TSH hormones were done at Unite of Biochemistry and Molecular Biology, Faculty of Medicine, Cairo University by ELIZA test.

2-Light microscopic examination: The thyroid glands were fixed in Bouin's solution for $48 \mathrm{hs}$. Later, they were dehydrated in graded levels of ethanol, cleared in xylene, and embedded in paraffin wax for sectioning. The 4-gm thick sections were cut, mounted on glass slides, and stained with hematoxylin and eosin stain to study the general features, Masson's trichrome stain to study the distribution of collagen fibers, periodic acid-Schiff (PAS) reactions to demonstrate the colloid content and toludine blue stain to study the presence of mast cells [15]. The images were taken by a microscope (Leica) DM750 connected to a digital camera in Anatomy Department, Faculty of Medicine for Girls, Al-Azhar University, Cairo,, Egypt.

3-Morphometric study: All studied groups were assessed by ordinary light microscope using an image analyzer computer system in the Pathology Department of Dental Medicine for girls, Al-Azhar University. It was used for measuring the epithelial heights of the follicular cells in Hx \& E stained sections in ten non overlapped fields within a standard measuring frame in magnification $x 400$. Connective tissue area percent in Masson's trichrome stained sections in ten non overlapped fields within a standard measuring frame of known area in magnification $\mathrm{x} 200$. Colloidal area percent in PAS stained sections in ten non overlapped fields within a standard measuring frame of known area in magnification $\mathrm{x} 200$. The equipment consisted of a digital camera attached to a light microscope and a computer system equipped with the software Leica Quin500, England capable of performing high aped digital image processing. The image analyzer was calibrated automatically to convert the measurement units (pixel) produced by the image analyzer program into actual micrometer units. The data was subjected to statistical analysis.

4- Statistical analysis: The data were collected and analyzed by SPSS (statistical package for social science) version 17.0 on IBM compatible computer. Statistical analysis of the data obtained were expressed as mean values and standard deviations, and statistical significance was determined by one-way analysis of variance (ANOVA) followed by post hoc analysis using LSD test for multiple comparison [16].

\section{Results}

\section{Biochemical results:}

Assessment of serum levels of freeT3, T4 and TSH:

The mean values of free T3, T4 of the induced hypothyroidism group (group II) showed highly significant decrease $(p<0.01)$ as compared to the control group (group I), while the mean value of TSH showed highly significant increase $(p<0.01)$ as compared to the control group (group I). Treatment of the induced hypothyroidism by BM-MSCs injection showed that after 6 weeks (III6), there were highly significance increase $(p<0.01)$ of mean values of serum level of T3 and T4 and highly significance decrease of mean value of serum level of TSH in compare to the induced hypothyroidism group but still there were significant decrease $(p<0.05)$ of mean values of free T3 and T4 and significance increase of mean value of TSH when compare with the control group. After 8 weeks (III8), there were highly significance increase $(p<0.01)$ of mean values of serum level of T3 and $\mathrm{T} 4$ and highly significance decrease of mean value of serum level of TSH in compare to the induced hypothyroidism group, but there were insignificant difference $(p>0.05)$ of mean values of free T3, T4 and TSH in compare to the control group. On the other hand, after 10 weeks from injection of BMMSCs (III10), there were insignificance differences $(p>0.05)$ of mean values of serum levels of T3, T4 and TSH in compare to the induced hypothyroidism group but still there were highly significant decrease $(p<0.01)$ of mean values of free T3 and T4 and highly significance increase of mean value of TSH 
when compare with the control group (group I) (Table 1 and Graphs $1,2,3$ ).

\section{Microscopic results:}

Microanatomy of the thyroid gland of the adult male albino rats of the control group: Examination of serial cross sections of the thyroid gland showed that the thyroid gland was covered by thin connective tissue capsule which sent thin ill-defined septa divided the gland into small lobules. The lobules contained many rounded or oval follicles of variable sizes. The peripheral follicles were relatively larger than the central follicles. The follicles had luminae filled with homogenous acidophilic substance called colloid. The colloid of peripheral follicles had peripheral vacuolations (Fig. 1a). Each follicle was surrounded by a thin basement membrane and lined by follicular cells (thyrocytes) arranged in a single layer of either cuboidal epithelium with rounded central nuclei or columnar epithelium with basal rounded nuclei (Fig. 2a). The cytoplasm of the follicular cells contained secretory granules in their apices. There were prominent cytoplasmic villi on the apices of the follicular cells extending into the lumen (Fig. 3a). There was another type of cells which were small oval and had dark stained nuclei compared with the follicular cells. These cells were called parafollicular cells or C cells. They were apparent few in number and situated between the follicular cells on the basement membrane. The follicles were separated from each other by scanty interstitial connective tissue which contained blood capillaries. Also, there were aggregations of multiple polygonal cells with central rounded nuclei called solid cell nest inbetween the follicles (Figs. 2a,3a). Masson Trichrome stain, showed the normal distribution of collagen fibers in the capsule, the connective tissue septa and in the wall of interstitial blood capillaries (Fig. 4a). There was a strong PAS positive reaction in the basement membrane of the follicles and it appeared more prominent in the colloid (Fig. 5a). Toludine blue stain showed few mast cells which were oval or spindle shaped with intense metachromasia masking their nuclei. These cells were present either near the follicular cells (perifollicular mast cell) or in the stroma between the follicles (stromal mast cell) (Fig. 6a).

Microanatomy of the thyroid gland of adult male albino rats of the experimentally induced hypothyroidism group: Examination of serial cross sections of the thyroid gland showed that the thyroid gland was covered by thin loose connective tissue capsule which sent septa divided the gland into small lobules. The lobules contained many follicles of variable sizes and shapes. The large follicles were located mainly at the periphery. The lumen of almost all follicles contained little amount of pale colloid with large peripheral vacuolations. Few follicles had no colloid (Fig. 1b). Each follicle was surrounded by thin basement membrane. The follicles were lined by either flat follicular cells with dark flat nuclei or cubical cells with dark central rounded nuclei (Fig. 2b). Most of these cells showed cytoplasmic vacuolations or became ballooned (Fig. 3b). The lumen of some follicles contained exfoliated cells with densely stained nuclei. There were also few degenerated follicles filled with pyknotic cells due to sloughing of follicular cells. The parafollicular cells were difficult to differentiate. There was an apparent widening in the interstitial spaces between the follicles and the follicles are fenestrated by large blood capillaries (Figs. 1b,2b). Masson Trichrome stain, showed loose collagen fibers deposition in the capsule, the septa and in the wall of interstitial blood capillaries (Fig. 4b). There were moderate positive PAS reaction of follicular basement membrane and in the colloid when present (Fig. 5b). By toludine blue stain, there were many small perifollicular and stromal mast cells mainly around the blood capillaries (Fig. 6b). Furthermore, the morphometric results clarified that there was highly significant decrease $(p<0.01)$ of the mean heights of follicular cells, area $\%$ of collagen fibers and area \% of colloid in group II (Induced hypothyroidism) compared to the control group (Table 2 and Graphs 4,5,6).

Microanatomy of the thyroid gland of the adult male albino rats of experimentally induced hypothyroidism treated with BM-MSCs intravenous injection group:

1- Subgroup III6: Examination of serial cross sections of the thyroid gland showed variable degree of response from mild to moderate to good response. The capsule was slightly thick and sent ill defined connective tissue septa divided the gland into small lobules. The follicles appeared compact. Most follicles were filled with colloid with some peripheral vacuolations. The interstitial space was nearly absent and still contained dilated and congested blood capillaries (Figs. 1c,2c). In mild response area, the thyroid follicles were lined by cubical cells with rounded central nuclei in some parts and lined by flat cells with flat nuclei in other parts. The cytoplasm of many follicular cells had apparently few dark secretory granules near their apices. Few follicular cells had cytoplasmic villi. There were many parafollicular cells situated on basement membrane (Fig. 3c). In moderate response 
area, the majority of the follicular cells were cuboidal with large rounded central nuclei. The cytoplasm of follicular cells had dark secretory granules near their apices and the cytoplasmic villi were more prominent. There were many parafollicular cells situated between the follicular cells on the basement membrane. Some thyroid follicles had honey comb appearance of its colloid (Fig. 3d). In good response area, the follicular cells were either cuboidal with large rounded central nuclei or columnar with large rounded basal nuclei similar to the control group. The cytoplasm of follicular cells had dark secretory granules near their apices and the cytoplasmic villi were more prominent. The parafollicular cells were situated between the follicular cells on the basement membrane (Fig. 3e). Solid cell nests appeared between the follicles when compared to the hypothyroidism induced group which was absent (Fig. 3c). Masson Trichrome stain, showed moderate collagen fibers deposition in the connective tissue septa and the wall of interstitial blood capillaries (Fig. 4c). There were variable degrees of reaction in the same field rang from strong, moderate and weak PAS positive reaction in the colloid and in the basement membrane of the follicles (Fig. 5c). By Toludine stain, there was apparent increase in number of perifollicular and stromal mast cells with increased areas of metachromasia (Fig. 6c). Furthermore, the morphometric results showed that there was highly significant increase $(p<0.01)$ of the mean heights of follicular cells, area $\%$ of collagen fibers and area $\%$ of colloid of the induced hypothyroidism treated after 6 weeks of BM-MSCs injection (group III6) in compared to the induced hypothyroidism group but still there was highly significant decrease $(p<0.01)$ of the mean heights of follicular cells and area $\%$ of colloid in compared to the control group (group I). While, there was insignificant difference $(p>0.05)$ of the mean values of area $\%$ of collagen fibers of the induced hypothyroidism treated after 6 weeks of BM-MSCs injection (group III6) in compared to the control group (group I) (Table 2 and Graphs 4,5,6).

2- Subgroup III8: Examination of serial cross sections of the thyroid gland of adult male rats of the induced hypothyroidism after 8 weeks of BMMSCs intravenous injection showed universal improvement of all examined fields more than the previous subgroup. The capsule was slightly thick. There were more compact thyroid follicles with variable size and shape (Fig. 1d). The luminae of all follicles were filled with a homogenous acidophilic colloid with few peripheral vacuolations. The interstitial spaces were nearly absent and there were more SCN between the follicles. Many folli- cles were lined by a single layer of columnar epithelium with apparently large rounded basal nuclei. Some follicular cells were cuboidal with apparently large rounded central nuclei (Fig. 2d). The cytoplasm was dense acidophilic and filled with secretory granules. The villi were more prominant. There were many parafollicular cells which situated within the basement membrane (Fig. 3f). Masson trichrome stain showed fine collagen fibers deposition in the capsule and the connective tissue septa (Fig. 4d). Strong PAS positive reaction was present in the basement membrane of the follicles and in the colloid (Fig. 5d). By Toludine stain, there were many perifollicular and stromal mast cells which appeared large in size with increased areas of metachromasia (Fig. 6d). Furthermore, the morphometric results showed that there was highly significant increase $(p<0.01)$ of the mean heights of follicular cells, area $\%$ of collagen fibers and area \% of colloid of the induced hypothyroidism treated after 8 weeks of BM-MSCs injection (group III8) in compared to the induced hypothyroidism group but still there was highly significant decrease $(p<0.01)$ of the mean heights of follicular cells in compared to the control group (group I). On the other hand, there was highly significant increase $(p<0.01)$ of the mean values of area $\%$ of collagen fibers of induced hypothyroidism after 8 weeks of BM-MSCs injection (group III8) in compared with the control group (group I). Also, there was insignificant difference $(p>0.05)$ of the mean values of area $\%$ of colloid of the induced hypothyroidism after 8 weeks of BMMSCs injection (group III8) in compared to the control group (group I) (Table 2 and Graphs. 4,5,6).

3- Subgroup III10: Examination of serial cross sections of the thyroid gland of adult male albino rats of the induced hypothyroidism after 10 weeks of BM-MSCs intravenous injection showed marked regression in response to SCs treatment as compared to previous two subgroups. The thyroid gland was covered by thin loose connective tissue capsule. It had variable size thyroid follicles. Some follicles lost their normal architecture. Many follicles were filled with colloid but some follicles had central vacuolations of their colloid (Figs. 1e,2e). Many thyroid follicles were lined by flat follicular cells with small dark flat nuclei and few follicles were lined by cubical cells with small dark rounded nuclei. The cytoplasm of many follicular cells showed vacuolations. Moreover, some cells had ballooned cytoplasm with compressed flat nuclei. In addition, some follicles had disrupted basement membrane. The parafollicular cells were few and difficult to differentiate. The interstitial spaces became wide again. However by screening exam- 
ination of the cross section, there was absence of SCN (Figs. 2e,3g). Masson trichrome stain showed mild collagen fibers deposition in the capsule and the connective tissue septa (Fig. 4e). Strong PAS positive reaction was present in the basement membrane of the follicles and in the colloid (Fig. $5 \mathrm{e})$. By Toludine blue stain, there were small scanty mast cells in the stroma with less areas of metachromasia than the previous subgroup (Figs. 6e,6d). Furthermore, the morphometric results showed that there was insignificant difference $(p>0.05)$ of the mean heights of follicular cells, area $\%$ of collagen fibers and area $\%$ of colloid of the induced hypothyroidism treated after 10 weeks of BMMSCs injection (group III10) in compared to the induced hypothyroidism group. In contrast, there was highly significant decrease $(p<0.01)$ of the mean heights of follicular cells, area $\%$ of collagen fibers and area \% of colloid of the induced hypothyroidism treated after 10 weeks of BM-MSCs injection (group III10) compared to the control group (group I) (Table 2 and Graphs 4,5,6).

Table (1): Mean values and standard deviations of the serum level of free T3, T4 and TSH of all experimental groups.

\begin{tabular}{lccc}
\hline Parameters & $\begin{array}{c}\text { Serum Level of free T3 } \\
\text { Mean } \pm \text { SD } \\
\text { Range }\end{array}$ & $\begin{array}{c}\text { Serum Level of free T4 } \\
\text { Mean } \pm \text { SD } \\
\text { Range }\end{array}$ & $\begin{array}{c}\text { Serum Level of TSH } \\
\text { Mean } \pm \text { SD } \\
\text { Range }\end{array}$ \\
\hline Control group (I) & $\begin{array}{c}74.38 \pm 1.09 \\
(72.6-76.4)\end{array}$ & $\begin{array}{c}3.40 \pm 0.43 \\
(2.8-4.1)\end{array}$ & $\begin{array}{c}0.09 \pm 0.00 \\
(0.09-0.1)\end{array}$ \\
$\begin{array}{l}\text { Induced hypothyroidism group } \\
\text { (II) }\end{array}$ & $\begin{array}{c}49.64 \pm 1.58 \\
(47.6-51.3)\end{array}$ & $1.86 \pm 0.45$ & $0.30 \pm 0.04$ \\
$\begin{array}{l}\text { Induced hypothyroidism treated } \\
\text { by Stem cells after 6weeks }\end{array}$ & $71.55 \pm 1.63$ & $(1.2-2.5)$ & $(0.24-0.36)$ \\
subgroup (III6) & $(68.7-73.9)$ & $2.96 \pm 0.15$ & $0.15 \pm 0.03$ \\
$\begin{array}{l}\text { Induced hypothyroidism treated } \\
\text { by Stem cells after 8 weeks }\end{array}$ & $74.64 \pm 1.04$ & $(2.6-3.09)$ & $(0.1-0.19)$ \\
subgroup (III8) & $(72.9-76.1)$ & $3.27 \pm 0.45$ & $0.11 \pm 0.02$ \\
$\begin{array}{l}\text { Induced hypothyroidism treated } \\
\text { by Stem cells after 10 weeks }\end{array}$ & $60.23 \pm 1.26$ & $(2.6-3.9)$ & $(0.09-0.14)$ \\
subgroup (III10) & $(58.3-62.1)$ & & $0.31 \pm 0.04$ \\
\hline
\end{tabular}

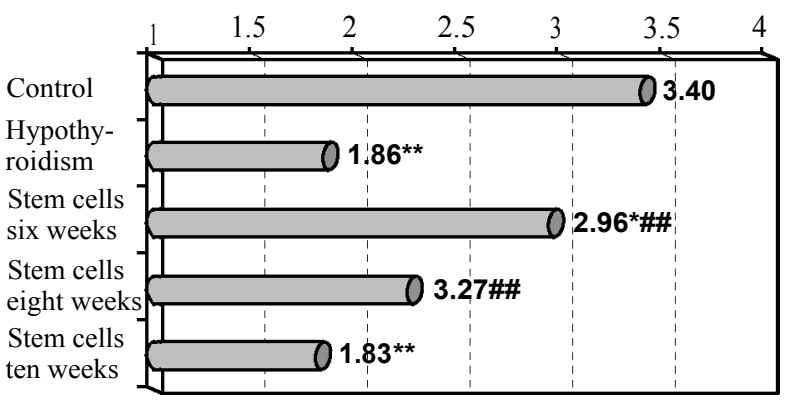

Graph (1): Mean values of serum level of T3 level. $\begin{array}{llllllllll}0 & 0.05 & 0.10 & 0.15 & 0.20 & 0.25 & 0.30 & 0.35\end{array}$

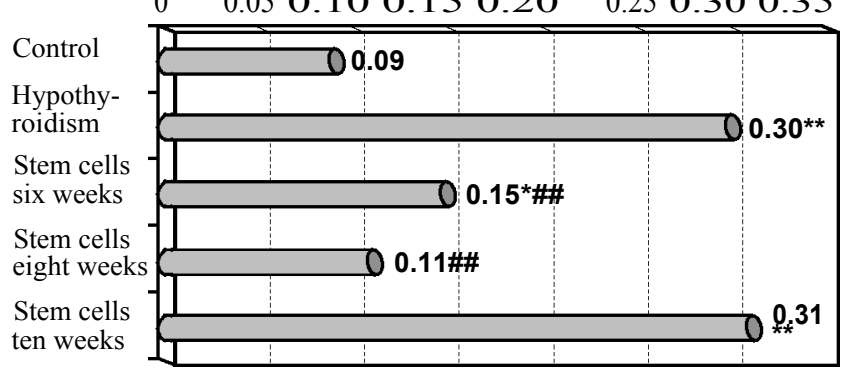

Graph (3): Mean values of serum level of TSH level.

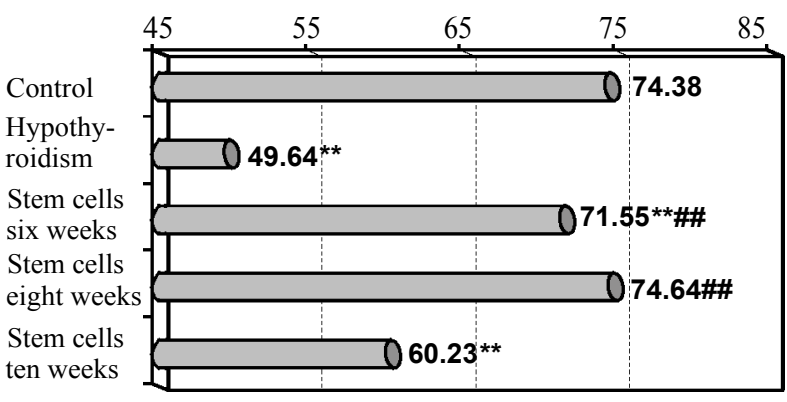

Graph (2): Mean values of serum level of T4 level.

\footnotetext{
- $(p$-value $>0.05$ for T3, T4 and TSH $)=$ Non significant.

- $(p$-value $<0.05$ for T3, T4 and TSH $)=$ Significant when compared with control group (*) and Significant when compared with induced hypothyroidism group (\#).

- $(p$-value $<0.01$ for T3, T4 and TSH $)=$ Highly significant when compared with control group $(* *)$ and highly significant when compared with induced hypothyroidism group (\#\#).
} 
Table (2): It shows the means and standard deviations of the heights of follicular cells, area \% of collagen fibers and area $\%$ of colloid of all experimental groups.

\begin{tabular}{|c|c|c|c|}
\hline $\begin{array}{l}\text { Parameters } \\
\text { Groups }\end{array}$ & $\begin{array}{c}\text { Heights of follicular cells } \\
\text { Mean } \pm \text { SD } \\
\text { Range }\end{array}$ & $\begin{array}{c}\text { Area } \% \text { of collagen fibers } \\
\text { Mean } \pm \text { SD } \\
\text { Range }\end{array}$ & $\begin{array}{c}\text { Area } \% \text { of colloid } \\
\text { Mean } \pm \text { SD } \\
\text { Range }\end{array}$ \\
\hline Control group (I) & $\begin{array}{l}15.82 \pm 4.01 \\
(8.4-23.75)\end{array}$ & $\begin{array}{l}8.42 \pm 2.46 \\
(4.25-12.39)\end{array}$ & $\begin{array}{l}23.90 \pm 7.44 \\
(15.35-36.01)\end{array}$ \\
\hline $\begin{array}{l}\text { Induced hypothyroidism group } \\
\text { (II) }\end{array}$ & $\begin{array}{l}5.42 \pm 1.71 \\
(2.1-8.6)\end{array}$ & $\begin{array}{l}3.20 \pm 1.53 \\
(1.23-6.17)\end{array}$ & $\begin{array}{l}3.97 \pm 1.86 \\
(0.73-6.8)\end{array}$ \\
\hline $\begin{array}{l}\text { Induced hypothyroidism treated } \\
\text { by Stem cells after } 6 \text { weeks } \\
\text { subgroup (III6) }\end{array}$ & $\begin{array}{l}10.68 \pm 2.58 \\
(6.18-16.2)\end{array}$ & $\begin{array}{l}10.07 \pm 3.14 \\
(5.37-14.99)\end{array}$ & $\begin{array}{l}15.75 \pm 4.60 \\
(9.43-23.77)\end{array}$ \\
\hline $\begin{array}{l}\text { Induced hypothyroidism treated } \\
\text { by Stem cells after } 8 \text { weeks } \\
\text { subgroup (III8) }\end{array}$ & $\begin{array}{l}13.25 \pm 2.82 \\
(8.55-18.01)\end{array}$ & $\begin{array}{l}12.97 \pm 5.52 \\
(4.72-19.26)\end{array}$ & $\begin{array}{l}19.52 \pm 4.47 \\
(12.38-27.42)\end{array}$ \\
\hline $\begin{array}{l}\text { Induced hypothyroidism treated } \\
\text { by Stem cells after } 10 \text { weeks } \\
\text { subgroup (III10) }\end{array}$ & $\begin{array}{l}4.58 \pm 1.18 \\
(2.1-6.7)\end{array}$ & $\begin{array}{l}5.99 \pm 2.28 \\
(2.66-10.73)\end{array}$ & $\begin{array}{l}12.97 \pm 4.32 \\
(5.8-20.62)\end{array}$ \\
\hline
\end{tabular}

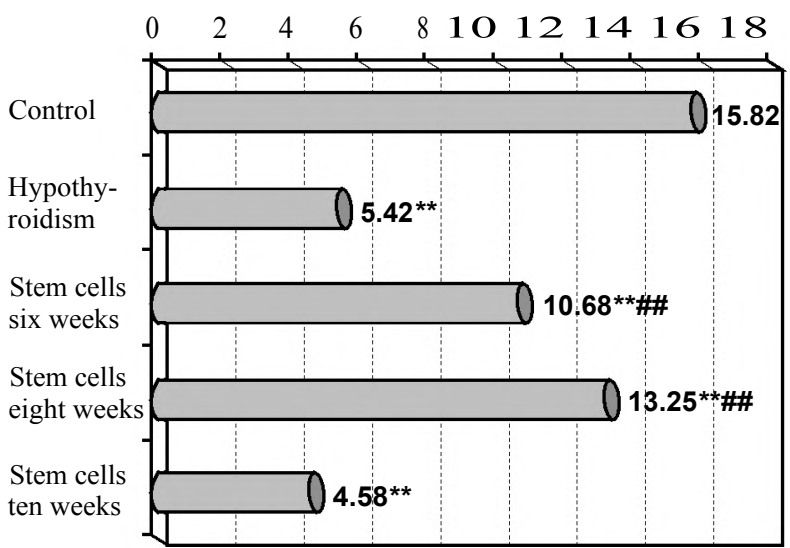

Graph (4): Mean values of level of Heights of follicular cells.

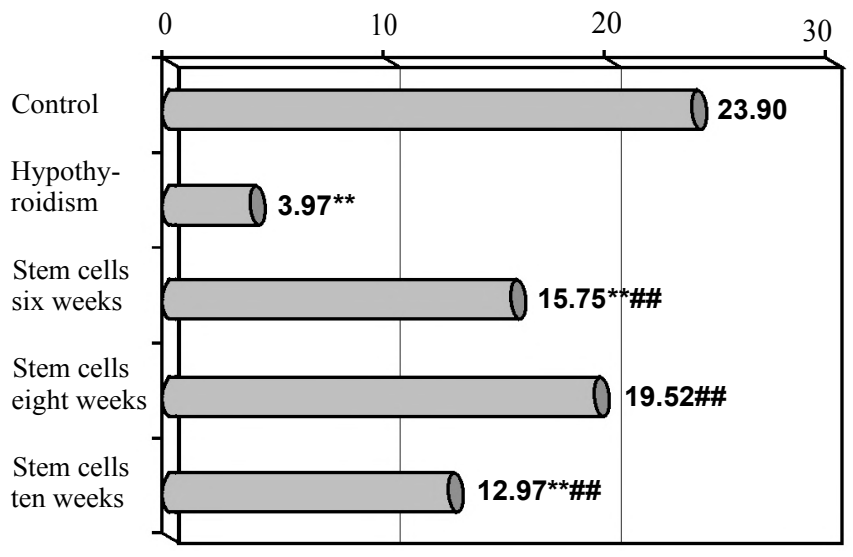

Graph (6): Mean values of area \% of colloid.

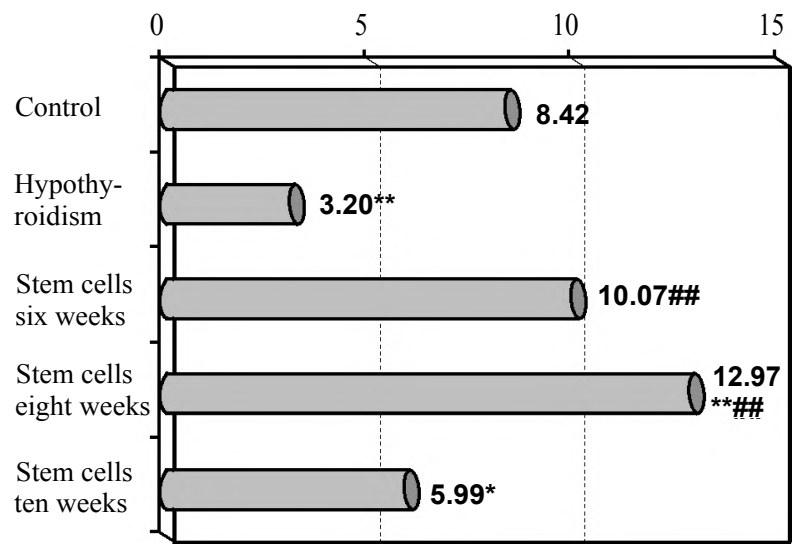

Graph (5): Mean values of area \% of collagen fibers.

- $p$-value $>0.05$ for heights, area $\%$ of collagen and area $\%$ of colloid $)=$ Non significant.

- ( $p$-value $<0.05$ for heights, area $\%$ of collagen and area $\%$ of colloid $)=$ Significant when compared with control group $(*)$ and Significant when compared with induced hypothyroidism group (\#).

- ( $p$-value $<0.01$ for heights, area $\%$ of collagen and area $\%$ of colloid) $=$ Highly significant when compared with control group $(* *)$ and highly significant when compared with induced hypothyroidism group (\#\#). 

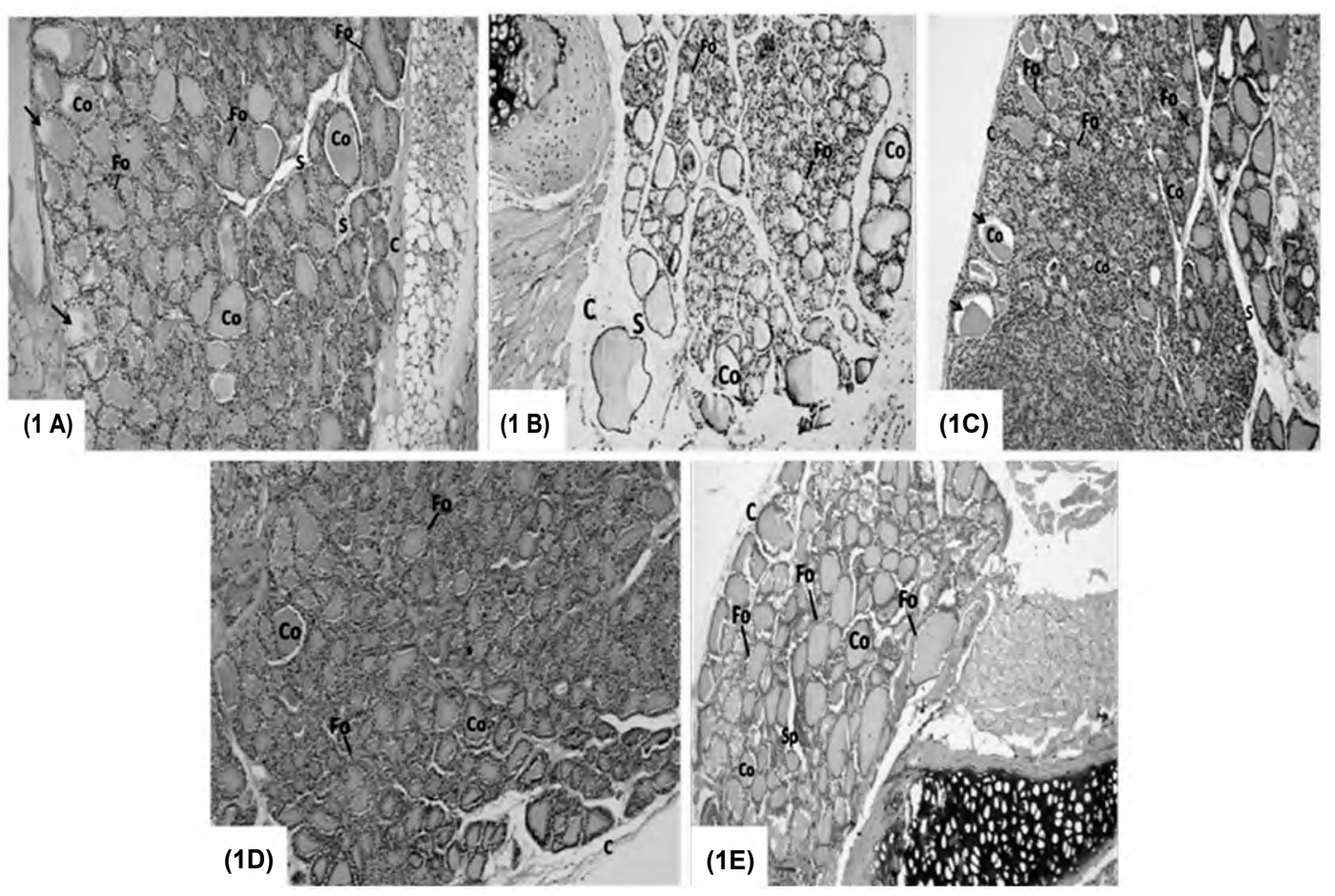

Fig. (1): Photomicrographs of cross sections of the thyroid glands of the adult male albino rats of all studied groups showed that:

Fig. (1a) control: The thyroid gland is surrounded by connective tissue capsule (C) which sends septa (S) dividing it into lobules; each of which contains many follicles ( $\mathrm{Fo}$ ) filled with colloid (Co). Notice that the peripheral follicles are relatively large and their colloid show peripheral vaculations (arrow).

Fig (1b): Induced hypothyroidism: The capsule is thin and loose (C) and the lumen of most of the follicles contain little amount of pale colloid with peripheral vacuolations (Co).

Fig. (1c): Induced hypothyroidism after 6 weeks of BM-MSCs injection: The capsule is slightly thick (C). Notice that almost all follicles filled with colloid (Co) except some of peripheral follicles have small peripheral vaculations (arrow).

Fig. (1d): Induced hypothyroidism after 8 weeks of BM-MSCs injection: The capsule is slightly thick (C). Notice that all the follicles are more compact and filled with colloid (Co)

Fig. (1e): Induced hypothyroidism after 10 weeks of BM-MSCs injection: The capsule is thin and loose (C). Notice that almost all follicles filled with colloid (Co) and the interstitial space is wide (Sp). (Hx. \&E. x100).
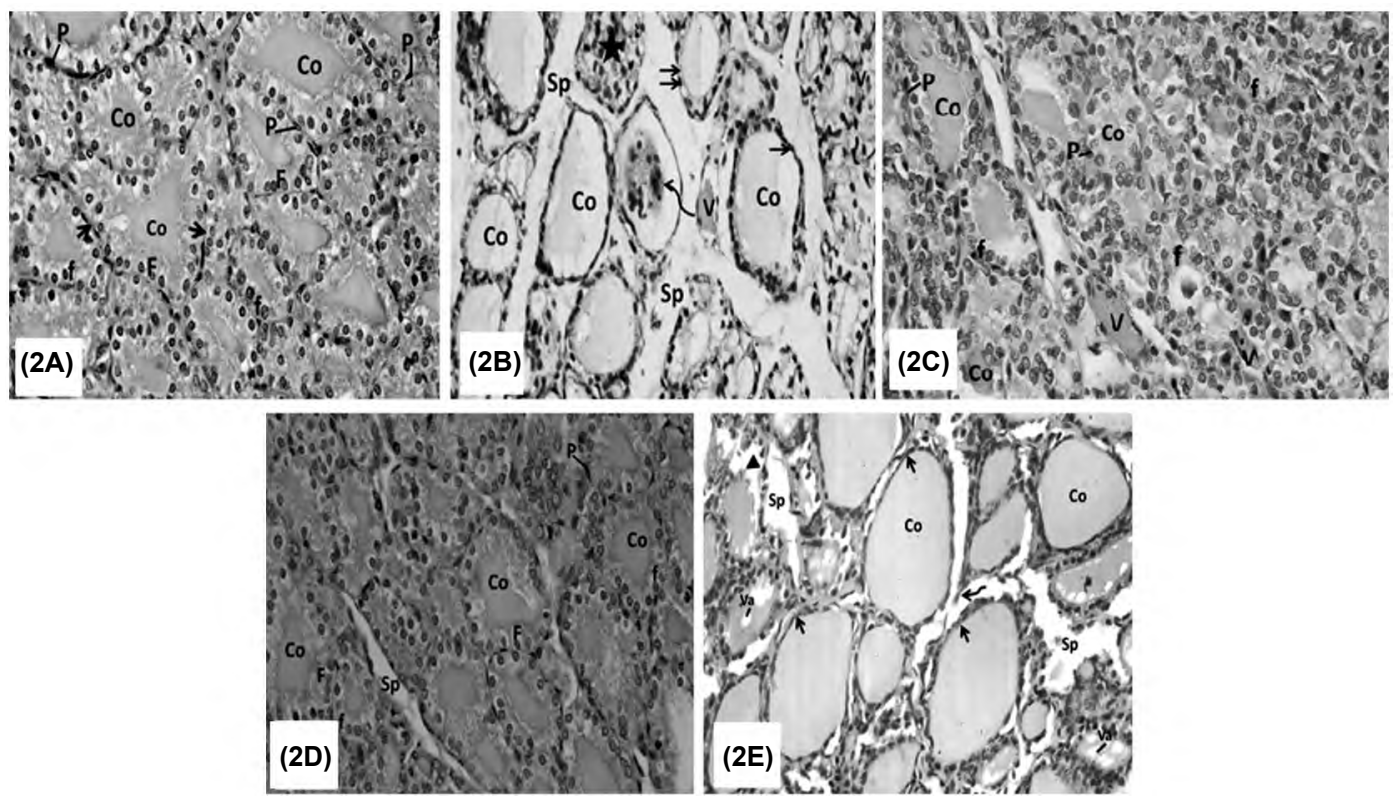

Fig. (2): Photomicrographs of cross sections of the thyroid glands of the adult male albino rats of all studied groups showed that:

Fig. (2a) control: The follicles are surrounded by thin basement membrane (arrow) and lined by follicular cells. The follicular cells are either cuboidal with central rounded nuclei (f) or columnar with basal rounded nuclei $(F)$. The luminae of the follicles are filled with homogenous acidophilic colloid (Co).The parafollicular cells are small oval and have dark stained nuclei and situated between the follicular cells on the basement membrane $(P)$.

Fig (2b) Induced hypothyroidism: The follicles are lined by flat (arrow) or cubical (double arrow) follicular cells on thin basement membrane Notice that one follicle has exfoliated follicular cells with densely stained nuclei in the lumen (zigzag arrow). Also there is one degenerated follicle filled with pyknotic cells (star). Most of the follicles have small amount of pale colloid with peripheral vacuolations (Co). Notice also that the interstitial spaces (Sp) between the follicles are wide and contain dilated blood capillaries $(\mathrm{V})$.

Fig. (2c) Induced hypothyroidism after 6 weeks of BM-MSCs injection: The follicles are lined by cuboidal follicular cells with large rounded central nuclei (f). There are many parafollicular cells $(P)$. Notice that almost all the follicles are filled with colloid $(\mathrm{Co})$. The interstitial spaces appear narrow with presence of dilated blood capillaries $(\mathrm{V})$.

Fig. (2d) Induced hypothyroidism after 8 weeks of BM-MSCs injection: Many follicles are lined by columnar follicular cells with basal nuclei (F) while some thyroid follicles are lined by cuboidal follicular cells with large rounded central nuclei (f). There are many parafollicular cells $(P)$. Notice that all the follicles are filled with colloid (Co). Notice that the interstitial space (Sp) is very narrow. Notice also the presence of SCN between follicles (SCN).

Fig. (2e) Induced hypothyroidism after 10 weeks of BM-MSCs injection: Many follicles are lined by flat follicular cells with flat nuclei (arrow). All the follicles are filled with colloid (Co) but some follicles have central vacuolation (Va). One follicle losses its normal architecture (arrow head) and some follicles have disrupted basement membrane (zigzag arrow). Notice that the interstitial space (Sp) is wide. (Hx. \&E. x400) 

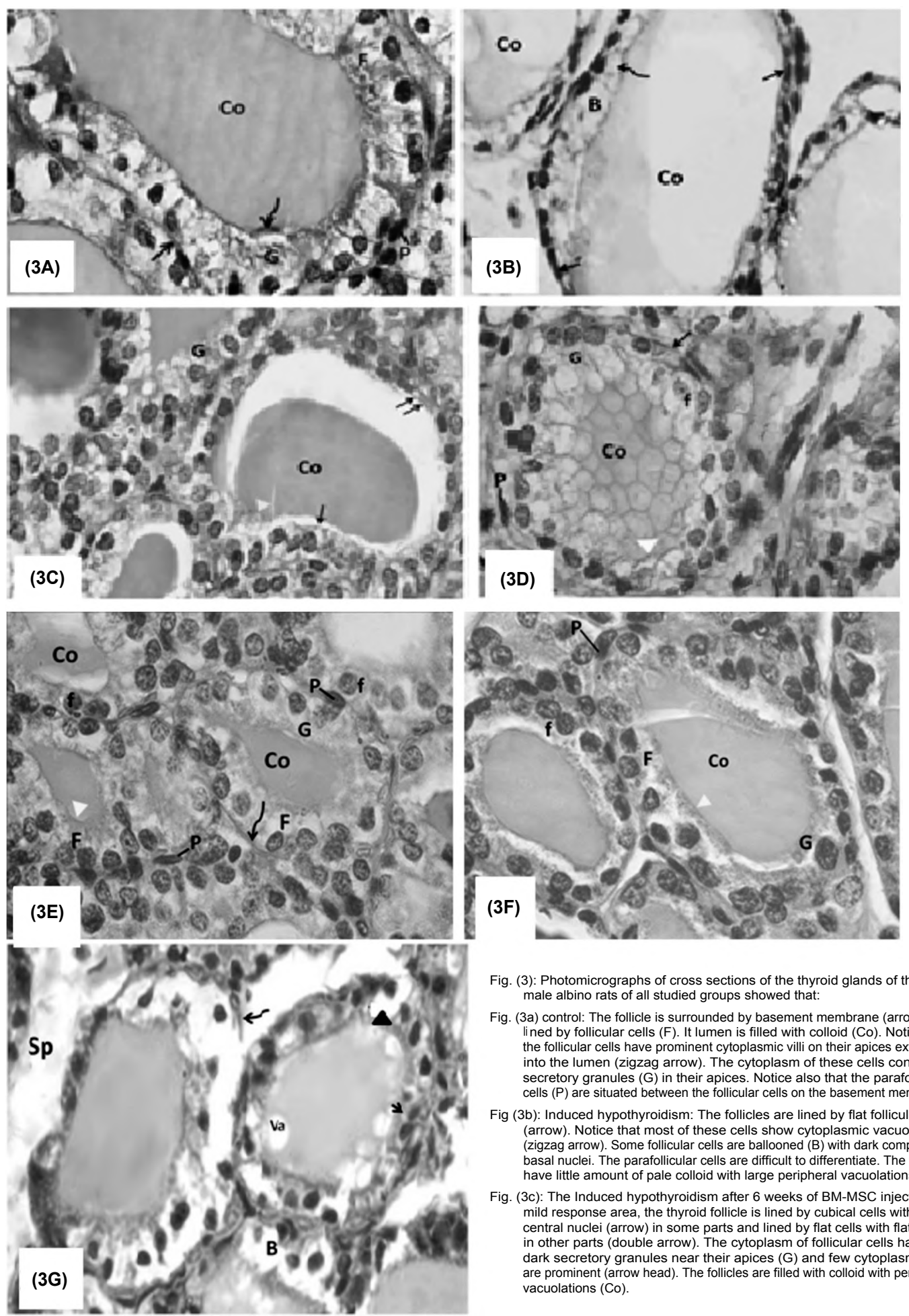

Fig. (3): Photomicrographs of cross sections of the thyroid glands of the adult male albino rats of all studied groups showed that:

Fig. (3a) control: The follicle is surrounded by basement membrane (arrow) and lined by follicular cells $(F)$. It lumen is filled with colloid (Co). Notice that the follicular cells have prominent cytoplasmic villi on their apices extending into the lumen (zigzag arrow). The cytoplasm of these cells contained secretory granules $(G)$ in their apices. Notice also that the parafollicular cells $(P)$ are situated between the follicular cells on the basement membrane.

Fig (3b): Induced hypothyroidism: The follicles are lined by flat follicular cells (arrow). Notice that most of these cells show cytoplasmic vacuolations (zigzag arrow). Some follicular cells are ballooned (B) with dark compressed have little amount of pale colloid with large peripheral vacuolations (Co).

Fig. (3c): The Induced hypothyroidism after 6 weeks of BM-MSC injection: In mild response area, the thyroid follicle is lined by cubical cells with round central nuclei (arrow) in some parts and lined by flat cells with flat nuclei in other parts (double arrow). The cytoplasm of follicular cells have few dark secretory granules near their apices (G) and few cytoplasmic villi
are prominent (arrow head). The follicles are filled with colloid with peripheral vacuolations (Co).

Fig. (3d): In moderate response area, the thyroid follicles are lined by cuboidal to columnar cells with large vesicular rounded central nuclei (F) and laying on thin basement membrane (arrow). The cytoplasm of follicular cells have dark secretory granules near their apices (G) and the cytoplasmic villi are prominent (arrow head). The parafollicular cells $(P)$ are situated between the follicular cells on the basement membrane. The thyroid follicle has honey comb appearance of its colloid (Co).

Fig. (3e): In good response area, some thyroid follicles are lined by cuboidal cells with large vesicular rounded central nuclei (f) and laying on thin basement membrane (zigzag arrow). Some follicles are lined by columnar cells with large vesicular rounded basal nuclei ( $F$ ). The cytoplasm of follicular cells have dark secretory granules near their apices $(G)$ and the cytoplasmic villi are prominent (arrow head). The parafollicular cells $(P)$ are situated between the follicular cells on the basement membrane. The apices (G) and the cytoplasmic villi
follicles are filled with colloid (Co)

Fig. (3f): Induced hypothyroidism after 8 weeks of BM-MSC injection: Some thyroid follicles are lined by cuboidal cells with central nuclei (f) while many follicles are lined by columnar cells with basal nuclei $(\mathrm{F})$. The cytoplasmic villi are prominent (arrow head) and the cytoplasm is filled with condensed dark secretory granules (G). There are many parafollicular cells $(P)$. Almost all follicles are filled with colloid $(\mathrm{Co})$.

Fig. (3g): Induced hypothyroidism after 10 weeks of BM-MSC injection: The thyroid follicles are lined by flat follicular cells with small dark flat nuclei (arrow). Notice the ballooning of cytoplasm of many follicular cells (B). In addition there are some follicular cells have vacuolated cytoplasm (arrow head). There are separation of contact between the disturbed basement membrane and the follicular cells (zigzag arrow). There are central vacuolation (Va) of the colloid. Notice also that the interstitial space $(\mathrm{Sp})$ return wide. (Hx. \&E. x1000). 

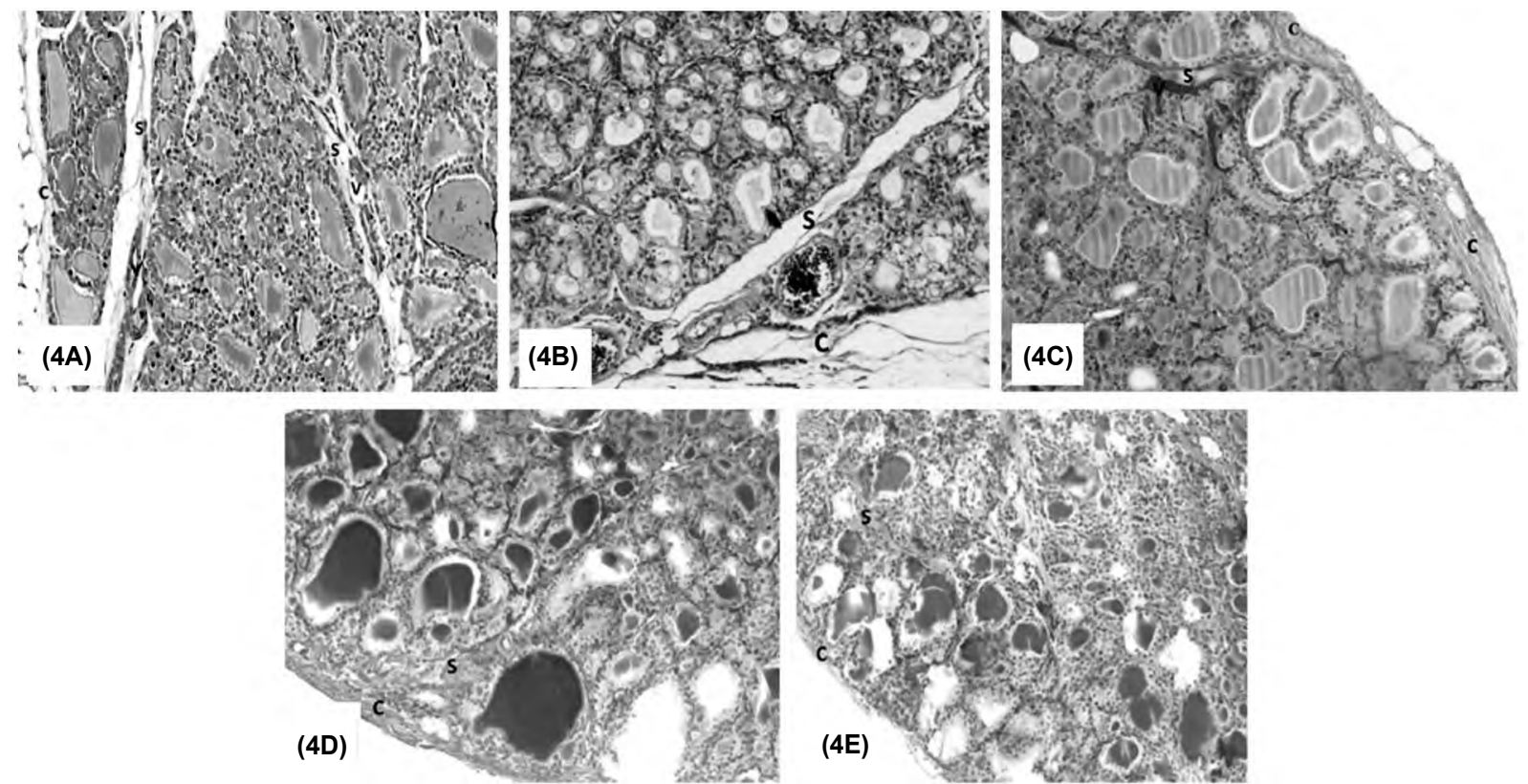

Fig. (4): Photomicrographs of cross sections of the thyroid glands of the adult male albino rats of all studied groups showed that:

Fig. (4a): control: Normal distribution of the collagen fibers in the capsule (C), the connective tissue septa (S) and in the wall of interstitial blood capillaries (V)

Fig. (4b,e): Induced hypothyroidism and induced hypothyroidism after 10 weeks of BM-MSC injection showing few loose collagen fibers deposition in the connective tissue capsule(C), septa (S) and the wall of blood capillaries (V) in the interstitial tissue between the follicles.

Fig. (4c,d): Induced hypothyroidism after 6 and 8 weeks of BM-MSC injection showing moderate deposition of collagen fibers in the capsule (C), the connective tissue septa (S) and the wall of blood vessels (V) in the interstitial tissue. (Masson Trichrome x200).

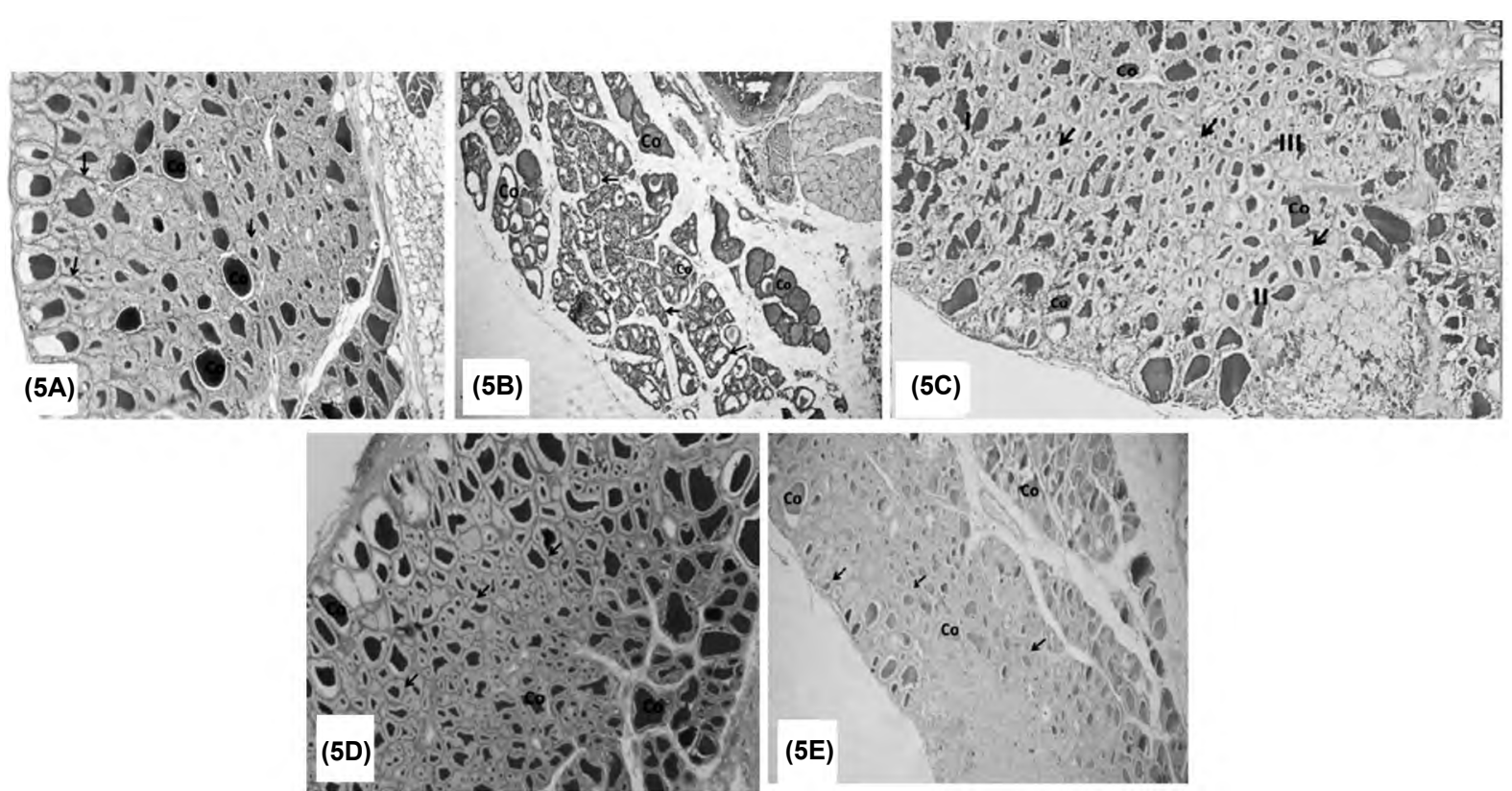

Fig. (5): Photomicrographs of cross sections of the thyroid glands of the adult male rats of all studied groups showed that:

Fig. (5a,d) control and Induced hypothyroidism after 8 weeks of BM-MSC injection showing strong PAS positive reaction in the basement membrane (arrow) of the follicles and it appears more prominent in the colloid (Co)

Fig. (5b,e): Induced hypothyroidism and Induced hypothyroidism after 10 weeks of BM-MSC injection: There is moderate PAS positive reaction of follicular basement membrane (arrow) and in the colloid (Co) when present.

Fig. (5c): Induced hypothyroidism after 6 weeks of BM-MSC injection: There are variable degrees of reaction from strong (I), moderate (II) and weak (III) in in the colloid (Co) and the basement membrane (arrow) of the follicles. (PAS x100). 

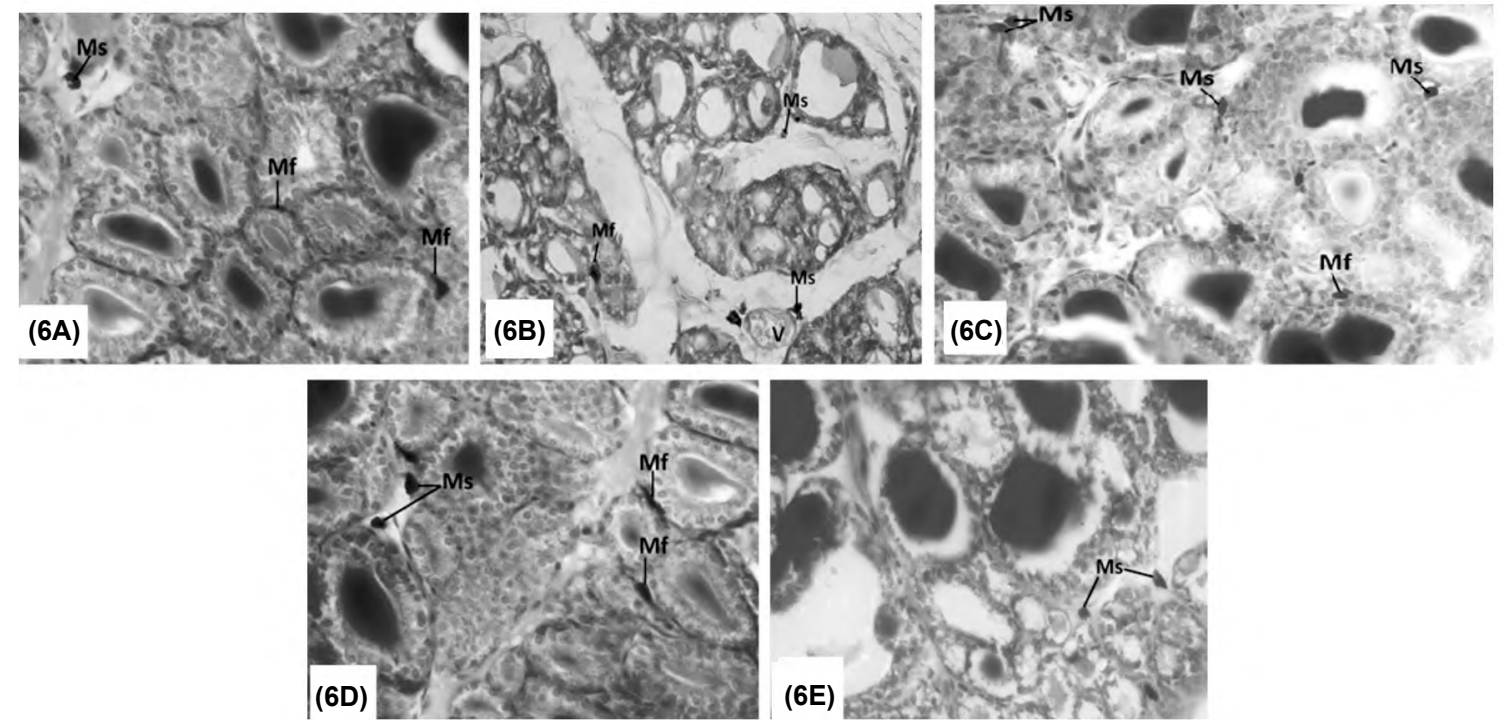

Fig. (6): Photomicrographs of cross sections of the thyroid glands of the adult male albino rats of all studied groups showed that:

Fig. (6a) control: Few mast cells which either oval or spindle shaped cells with intense metachromasia masking their nuclei. They are either present near the thyrocytes, perifollicular mast cell (Mf) or present in the stroma, stromal mast cell (Ms).

Fig (6b): Induced hypothyroidism: There are many apparently small perifollicular mast cells (Mf) and stromal mast cells (Ms) mainly present around the blood capillaries $(\mathrm{V})$.

Fig. (6c, 6d): Induced hypothyroidism after 6 and 8 weeks of BM-MSC injection: There are many perifollicular mast cells (Mf) and stromal mast cell (Ms) with increase areas of metachromasia.

Fig. (6e): Induced hypothyroidism after 10 weeks of BM-MSC injection: There are small scanty mast cells in the stroma (Ms) with less areas of metachromasia (TB $\times 400)$.

\section{Discussion}

Biochemical study of the experimentally induced hypothyroidism group (group II) proved evidences of hypothyroidism whereas the serum levels of free T3 and T4 were low with highly significance decrease in compare to the control group. Also, the serum level of TSH was high with highly significance increase in compare to the control group. The serum levels of the thyroid hormones seemed to reflect the disturbed histological features in the thyroid gland. Similar suggestion was reported by Zaidi et al., (2004) [17]. Milosevic et al., (2004) [18] clarified that the thyroid gland activity was regulated by hypothalamic pituitary thyroid axis, including negative feedback loop. The authors pointed to TSH as a major growth factor for the thyroid. The thyroid gland under high TSH underwent enlargement, neovascularisation and morphological alterations of the thyrocytes.

In the present study, examination of serial cross sections of the thyroid gland of adult male albino rats of the induced hypothyroidism group showed that the thyroid gland was covered by loose connective tissue capsule. The follicles were lined by either flat follicular cells with dark flat nuclei or cubical cells with dark central rounded nuclei. Most of these cells showed cytoplasmic vacuolations or became ballooned. The lumen of almost all follicles contained small amount of pale colloid with peripheral vacuolation and few follicles had no colloid. These finding were suggested to be due to hypoactivty of the thyroid gland with fluid accumulation and glandular over stimulation by high TSH which confirmed statistically by highly significance decrease of the heights of follicular cells in compare to the control group. This suggestion went hand in hand with Serakides et al., (1999) [19] and Elkalawy et al., (2013) [20]. Furthermore, Rubin and Strayer (2008) [21] explained that hydropic swelling resulted from impairment of cellular volume regulation with accumulation of sodium in the cell led to an increase in water content to maintain isoosmotic conditions and consequently caused cell swelling.

In the current study, the lumen of some follicles contained exfoliated cells with densely stained nuclei. There were few degenerated follicles filled with pyknotic cells due to sloughing of follicular cells in addition to the presence of widening in the interstitial spaces between the follicles. These finding might be due to loss of cell support and hydropic degeneration of the interstitial tissue with the presence of interstitial oedema. Another explanation was reported by El Bekry and Tawfik (2014) [22] who mentioned that collapse of some follicles or necrosis of the other follicles leaving empty spaces lead to widening in the interstitial spaces.

Masson trichrome stained thyroid sections of the induced hypothyroidism group showed that there was an apparent widening in the interstitial 
spaces with loose thin collagen fiber deposition in the connective tissue capsule, septa and the wall of blood capillaries which confirmed statistically by highly significance decrease of area $\%$ of collagen fibers in compare to the control group. Similar observation was reported by Abdel-Dayem and Elgendy (2009) [23]. PAS stained thyroid showed irregular shaped follicles that exhibited moderate positive PAS reaction of follicular basement membrane and in the colloid when present which confirmed statistically by highly significance decrease of area $\%$ of colloid in compare to the control group. The referred cause might be related to increased demand to thyroid hormones which stored in thyroid colloid and the empty thyroid lumenae might be due to more extraction of stored thyroid colloid to meet the hypothyroidism state. The findings of the present study were similar to Rubin and Strayer (2008) [21] and El Bekry and Tawfik (2014) [22]. In toludine blue stained thyroid sections of this group, there were many mast cells in the interstitial tissue mainly around the blood capillaries. This increment may be due to tissue compensatory mechanism to overcome the effect of hypothyroidism whereas the mast cells were a corner stone in the thyroid repair, it has the ability to act as angiogenesis and folliculogensis. These suggestions were in agreement with Abd-El Aty and Badr El-Din (2015) [24].

In the present study, examination of the thyroid gland of the adult male albino rats of induced hypothyroidism after 6 weeks of intravenous injection of BM-MSCs showed variable degrees of improving. However, the thyroid gland became nearly similar to the control group. The serum levels of free T3 and T4 showed highly significance increase and the serum level of TSH was highly significance decrease in compare to the induced hypothyroidism group. While the serum levels of free T3 and T4 still showed highly significance decrease and the serum level of TSH was highly significance increase in compare to the control group. While after 8 weeks, the serum levels of free T3 and T4 were highly significance increase and serum level of TSH was highly significance decrease in compare to the induced hypothyroidism group. The serum levels of free T3, T4 and TSH were insignificance difference in compare to the control group. These results confirmed that BMMSCs could compensate the induced defect. In histological examination after 6 weeks of injection of BM-MSCs, the capsule was slightly thick. The follicular cells had different shapes, some of them were cuboidal with large rounded central nuclei, some were columnar with large rounded basal nuclei and others were cubical with rounded central nuclei with intense vascularisation in between the follicles. These finding confirmed statistically by highly significant increase of the mean heights of follicular cells in compared to the induced hypothyroidism group but still there was highly significant decrease of the mean heights of follicular cells in compared to the control group. Many thyroid follicles were filled with colloid with peripheral vacuolations and this might indicated active thyroid follicles. These finding confirmed that the thyroid gland partially restored its normal histological pattern. The explanation of this partial restoration referred to the ability of the BM-MSCs to differentiate to thyrocytes in the presence of acceptable level of thyroid hormones and stoppage of administration of the trigger (carbimazole). Similar observation was reported by Salinas et al., (2007) [25]. The authors added that the active thyroid follicle extracted the stored thyroid colloid from the lumen and converted it into active thyroid hormones and the scalloped pale edge of the colloid indicated where the colloid had been removed from the follicle lumen. After 8 weeks from BM-MSCs injection, the histology of thyroid gland became apparently similar to the control group. Many follicles were lined by a single layer of columnar epithelium with apparently large rounded basal nuclei and some follicular cells were cuboidal with apparently large rounded central nuclei which confirmed statistically by insignificance difference of the heights of follicular cells in compare to the control group and highly significant increase of the mean heights of follicular cells in compared to the induced hypothyroidism group. Similar study was performed by Mikhailov et al., (2012) [26] who found that the injection of BM-MSCs contributes in follicular epithelium renewal.

The improvement in thyroid gland function and structures after 8 weeks from BM-MSCs injection appeared to be due to the migration of injected BM-MSCs to thyroid gland. Tao et al., (2016) [27] confirmed that as they found that stem cells migrated into the target organ and differentiated into a variety of cells, including vascular endothelial cells, thus revealing that BM-MSCs might contribute to regeneration of target organ by enhancing angiogenesis. Another explanation to the improvement with BM-MSCs was their paracrine effect. This was confirmed by Hu et al., (2017) [28] who reported that BM-MSCs paracrine activity had an anti-inflammatory effect and an antiapoptotic effect on intervertebral disc degeneration and this was mediated by nuclear factor-KB and mitochondrial apoptotic pathways in annulus fibrosus cells. Zuo et al., (2019) [29] added that a new specific secretory vesicles which involved in the paracrine effects of 
BM- MSCs are called exosomes It plays important role in repairing, improved safety and reduced immune rejection.

In this group, there were many large SCN appeared between the follicles when compared to the hypothyroidism induced group which was nearly absent. This might be due to its ability to rearrange as new follicles. Thomas et al., (2008) [30] reported that the main cells of solid cell nests of the human thyroid gland have some SCs properties, including a capacity for self renewal and an ability to differentiate into more than one cell type.

In Masson trichrome stained thyroid sections after 6 and 8 weeks of BM-MSCs injection, there were moderate collagen fiber deposition in the capsule, the connective tissue septa and the wall of blood vessels in the interstitial tissue between the follicles which confirmed statistically by highly significance increase of area $\%$ of collagen fibers in compare to the induced hypothyroidism group. While there was insignificance difference of area $\%$ of collagen fibers in subgroup III6 in compare to the control group and highly significance increase in subgroupIII8 in compare to the control group. Isacksona et al., (2013) [31] reported that BMMSCs increased vascularization, increased cellularity and increase collagen content. It is suggested that BM-MSCs produced these effects through two suggested mechanisms through paracrine signaling mechanisms and differentiation into resident cells.

In PAS stained thyroid sections after 6 weeks of BM-MSCs injection, there were variable degrees of reaction from strong, moderate and weak in the colloid and in the basement membrane of the follicles which confirmed statistically by highly significance increase of area \% of colloid in compare to the induced hypothyroidism group but still highly significance decrease of area \% of colloid in compare to the control group. On the other hand, in PAS stained thyroid sections after 8 of BM-MSCs injection, there were strong reaction in the colloid and in the basement membrane of the follicles which confirmed statistically by highly significance increase of area $\%$ of colloid in compare to the induced hypothyroidism group and insignificance difference in compare to the control group. These findings seemed to be similar to Abdul-Hamid and Salah (2013) [32] and Kassab and El-Aasr (2018) [33].

Regarding the toludine blue stained thyroid section, there were many mast cells; perifollicular and stromal mast cell with increased areas of metachromasia present around blood vessels which indicate its role in regeneration of the follicles. Toda et al., (2001) [34] demonstrated that in thyroid regeneration, the number of mast cells increased near blood capillaries. They were closely associated with connective tissue remodeling and localized at the thyroid tissue regenerative site where both thyroid folliculogenesis and angiogenesis took place.

In the current study, examination of rats of induced hypothyroidism after 10 weeks of BMMSCs injection showed progressive downward response to SCs treatment as compared to the previous subgroups. The serum levels of free T3, $\mathrm{T} 4$ and TSH were insignificance difference in compare to the induced hypothyroidism group. On the other hand, the serum levels of free T3, T4 were highly significance decrease and the serum level of TSH was highly significance increase in compare to the control group. In histological examination, the capsule was thin and loose. The basement membrane of some follicles was disrupted and few follicles lost its normal architecture. The follicular cells became either flat with small dark flat nuclei or cubical cells with small dark rounded nuclei which confirmed statistically by highly significance decrease of height of follicular cells in compare to the control group and insignificance difference in compare to the induced hypothyroidism group. Some follicular cells had cytoplasmic vacuolations and few cells were ballooned with compressed flat nuclei. The parafollicular cells were few and difficult to differentiate. The luminae of many follicles filled completely with colloid but some had central vacuolation of its colloid. The interstitial space was wide and showed dilated and congested blood capillaries. The cells nest had disappeared. Masson trichrome stain, showed mild collagen fibers deposition in the capsule and the connective tissue septa which confirmed statistically by highly significance decrease of area $\%$ of collagen fibers in compare to the control group and insignificance difference in compare to the induced hypothyroidism group. Strong PAS positive reaction was present in the basement membrane of the follicles and in the colloid but statistically there was highly significance decrease of area \% of colloid in compare to the control group but highly significance increase in compare to the induced hypothyroidism group. By Toludine blue stain, there were small scanty mast cells in the stroma with less areas of metachromasia than the previous subgroups. These finding indicated that BM-MSCs failed to maintain their action in regeneration and folliculogenesis. A lot of causes could be contributed in this condition which mentioned by Wolf (2009) [35] who 
reported that SCs graft failure might be due to an inadequate numbers of transplanted SCs or the failure of adequate number of these cells to survive. The authors added that the barriers to engraftment included immunologic destruction, infectious agents, drug toxicity or a poor bone marrow microenvironment. Herberts et al., (2011) [36] mentioned that the risk factor of use of SCs might be the potential high number of cells needed for the beneficial effect. It is generally unknown how many cells are needed, however, given the very low rate of retention and possible low cell survival, large number of cells may be required for obtaining maximal clinical benefit. In the same time, injection of concentrated cells into tissue may have unwanted effects. Hao et al., (2018) [37] studied the effects of multiple intravenous infusions of BM-MSCs in treatment of experimental type 2 diabetes rats. They said that single dose of BM-MSCs infusion ameliorated hyperglycemia and relived the drug induced pancreatic damage but these effects only maintained for 2-3 weeks. Also single dose injection failed to restore normoglycemia in diabetic animals so they did multiple injections of BM-MSCs with 2 weeks interval between each dose. They found that multiple BM-MSCs injection reversed the hyperglycemia and restored the damaged pancreatic tissue.

\section{Conclusion and recommendations:}

It could be concluded that injection of single dose of BM-MSCs partially restored the function and histological structures of the thyroid gland of male adult albino rats after experimentally induction of hypothyroidism. This improvement was clearly observed after 8 weeks from BM-MSCs injection. However, progressive downward response occurred after 10 weeks. So, another dose of BM-MSCs is recommended.

\section{References}

1- BRUNTON LL., CHABNER B. A. and KNOLLMANN B.C.: Goodman \& Gilman's The Pharmacological Basis of Therapeutics. $12^{\text {th }}$ ed., McGraw-Hill, pp. 1059-80, 2012.

2- SAKR S.S., SOBHY E.H., YOSRY A.O., ISLAM M.E., et al.: Cytoprotective effects of aqueous ginger (zingiber officinale) extract against carbimazole-induced toxicity in albino rat. E.J.P.M.R., 3 (7): 489-97, 2016.

3- COUGHLIN R.P., OLDWEILER A., MICKELSON D.T. and MOORMAN C.T.: Adipose-derived stem cell transplant technique for degenerative joint disease. Arthroscopy Techniques, 6 (5): 1761-6, 2017.

4- TUCH B.E.: Stem cells clinical update. Australian Family Physician, 35 (9): 719-21, 2006.

5- MLSNA E. and LUCAS J.: Stem cell based treatments and novel considerations for conscience clause legislation.
Indiana Health Law Review. United States, 8 (2): 47196, 2010.

6- MORRISON S.J. and SPRADLING A.C.: Stem cells and niches: Mechanisms that promote stem cell maintenance throughout life. Cell J., 132 (4): 598, 2008.

7- VOLAREVIC V., BOJIC S., NURKOVIC J., VOLAREVIC A., et al.: Stem cells as new agents for the treatment of infertility: current and future perspectives and challenges. Biomed. Res. Int., 13 (9): 1-8, 2014.

8- SACCHETTI B., FUNARI A., MICHIENZI S. and CESARE S.: Self-renewing osteoprogenitors in bone marrow sinusoids can organize a hematopoietic microenvironment. Cell, 131 (2): 324-36, 2007.

9- https://Pubchem.ncbi.nlm. nih.gov/compound/Carbimazole/31072. 2017.

10- EUROPA C.E., VALDIVIA B.V., LOPEZ E.G., COLIN F.M., et al.: Methomizole induced hypothyroidism causes alternation of REDOX environment, oxidative stress and hepatic damage. Annual of Hepatology, 9 (1): 80-8, 2010.

11- ALHADLAQ A. and MAO J.: Mesenchymal stem cells: isolation and therapeutics. Stem. Cells. and Development., 4 (13): 1-7, 2004.

12- SANGEETHA P., MAITI S.K., DIVYA M., SHIVARAJU S., et al.: Mesenchymal stem cells derived from rat bone marrow (rBM MSC): Techniques for isolation, expansion and differentiation. Journal of Stem. Cell Research \& Therapeutics, 3 (3): 272-9, 2017.

13- NADRI S., MASOUD S., REZA H.H., MOHAMMAD M., et al.: An efficient method for isolation of murine bone marrow mesenchymal stem cells. Int. J. Dev. Biol., 51: 723-9, 2007.

14- ZHANG D., LIU X., PENG J. and LIN T.: Potential spermatogenesis recovery with bone marrow mesenchymal stem cells in an azoospermic rat model. Int. J. Mol. Sci., 15 (8): 13151-65, 2014.

15- BANCROFT J.D. and GAMBLE M.: Theory and practice of Histological Techniques. The $7^{\text {th }}$ ed. Philadelphia: Churchill Livingstone of Elsevier, pp. 172-186, 2013.

16- MOULD R.F.: Introductory medical statistics. 2nd ed., Adam Hilger, Bristol. and Philadelphia, pp. 17-26, 1989.

17- ZAIDI T.M., KHAN A.A., HASAN B.M. and FARUQI A.N.: Carbimazole induced thyroid histopathy in albino rats during development. J. Anat. Soc. India, 53 (2): 1417, 2004.

18- MILOSEVIC C., KORA A. and DAVIDOVI V.: Methimazole-induced hypothyroidism in rats: Effects on body weight and histological characteristics of thyroid gland. Jugoslov Med. Biohem., 23: 143 -7, 2004.

19- SERAKIDES V.A., NUNES R.L., SANTOS G.D. and CASSALI P.P.: Histomorphometry and Quantification of Nucleolar Organizer Regions in Bovine Thyroid Containing Methylthiouracil Residues. Vet. Pathol., 36: 574-82.

20- ELKALAWY A.M., ABO-ELNOUR R.K., EL DEEB F and YOUSRY M.M.: Histological and immunohistochemical study of the effect of experimentally induced hypothyroidism on the thyroid gland and bone of male albino rats. Egypt J. Histol., 36 (1): 1-10, 2013. 
21- RUBIN R. and STRAYER D.: Rubin's Pathology: Clinicopathologic Foundations of Medicine. 1 st ed., Lippincott Williams \& Wilkins, p. 955, 2008.

22- ELBEKRY R.H and TAWFIK M.S.: Histological study of the effect of potassium dichromate on the thyroid follicular cells on adult male albino rats and possible protective role of ascorbic acid (Vit C). Journal of Microscopy and Ultrastructure, 2: 137-50, 2014.

23- ABDEL-DAYEM M.M. and ELGENDY M.S.: Effects of chronic estradiol treatment on the thyroid gland structure and function of ovariectomized rats. Bio. Med. Center, 2: 1-7, 2009.

24- ABD-EL ATY O.A. and BADR EL-DIN S.: Effect of sitagliptin (januvia) on the thyroid gland of adult male albino rats in an experimental model of type ii diabetes mellitus-biochemical, histological and immunohistochemical studies. Basic Sciences of Medicine, 4 (3): 38-51, 2015.

25- SALINAS G.E., CARVAJAL J.A., RAMOS A.A., ARROYO L., et al.: Effects of bone marrow cell transplant on thyroid function in an I131-induced low T4 and elevated TSH rat model. J. Negat. Results Biomed., 18 (6): 1-9, 2007.

26- MIKHAILOV V.M. SOKOLOVA A.V., SERIKOV V.B., KAMINSKAYA E.M., et al.: Bone marrow stem cells repopulate thyroid in $\mathrm{X}$-ray regeneration in mice. Pathophysiology, 19: 5-11, 2012.

27- TAO H., HAN Z., ZHONG C.H. and ZONGJIN L.: Proangiogenic features of mesenchymal stem cells and their therapeutic applications. Stem Cells International, 8: 1$11,2016$.

28- HU J., QIANG Y., CHANGGUI S., YE T., et al.: BMSC paracrine activity attenuates interleukin-1 (3-induced inflammation and apoptosis in rat AF cells via inhibiting relative NF- $\mathrm{KB}$ signaling and the mitochondrial pathway. Am. J. Transl. Res., 9 (1): 79-89, 2017.
29- ZUO R., LIU M., WANG Y., LI J., et al.: BM-MSCderived exosomes alleviate radiation-induced bone loss by restoring the function of recipient BM-MSCs and activating Wnt/(3-catenin signaling. Stem Cell Research and Therapy, 10 (30): 1-13, 2019.

30- THOMAS D., FRIEDMAN S. and YI LIN R.: Thyroid stem cells: lessons from normal development and thyroid cancer. Endocr. Relat. Cancer, 15 (1): 51-8, 2008.

31- ISACKSONA B., KEVIN J., COOKA B., LAWRENCE D., et al.: Mesenchymal Stem Cells Increase Collagen Infiltration and Improve Wound Healing Response to Porous Titanium Percutaneous Implant. Med. Eng. Phys., 35 (6): 743-53, 2013

32- ABDUL-HAMID M. and SALAH M.: Lycopene reduces deltamethrin effects induced thyroid toxicity and DNA damage in albino rats. The Journal of Basic \& Applied Zoology, 66: (4): 155-63, 2013.

33- KASSAB A.A. and EL-AASR M.: Effect of Avocado pulp extract on chlorpyrifos-induced thyroid gland injury in rats: A histological and morphometric study E.J.H Journal, 41 (1): 83-91, 2018.

34- TODA S., KOIKE N. and SUGIHARA H.: Thyrocyte integration, and thyroid folliculogenesis and tissue regeneration, perspective for thyroid tissue engineering. Pathol. Int., 51: 403-17, 2001.

35- WOLFF S.: Second hematopoietic stem cell transplantation for the treatment of graft failure, graft rejection or relapse after allogeneic transplantation. Bone Marrow Transplantation, 29, 545-552, 2002.

36- HERBERT C., KWA S.G. and HARM P.H.: Risk factors in the development of stem cell therapy. Journal of Translational Medicine, 9 (1): 1-29, 2011.

37- HAO H., JIEJIE L., JING S., YALI Z., et al.: Multiple intravenous infusions of bone marrow mesenchymal stem cells reverse hyperglycemia in experimental type 2 diabetes rats. Biochemical and Biophysical Research Communications, 436: 418-23, 2013. 


\section{دور الخلايا الجذعية فى علاج قصور الغدة الدرقية المستحدث

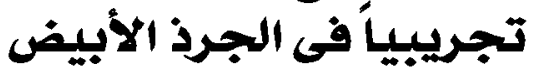

الخلفية: قصور الغدة الدرقية هي حالة شائعة ذو عواقب صحية مدمرة وقاردة تنتثر فى جميع أنحاء العالم. وقد أظهر العلاج بالخلايا

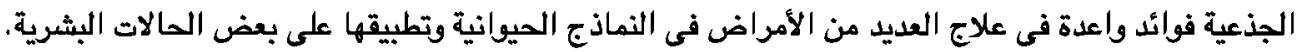

الهدف من العمل: دراسة تأثير الخلايا الجذعية للنخاع العظمى على تركيب البيوكيميائى والنسيجى اللغدة الدرقية المستحدث تجريياً فى

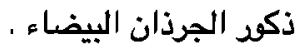

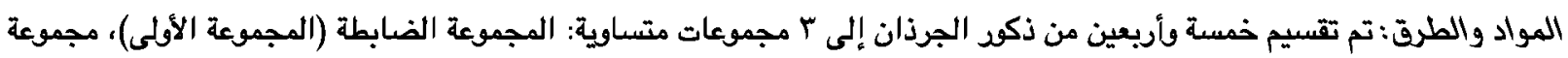

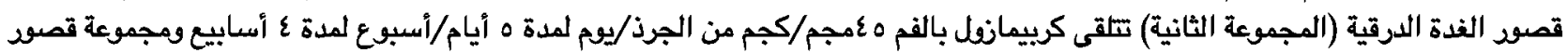

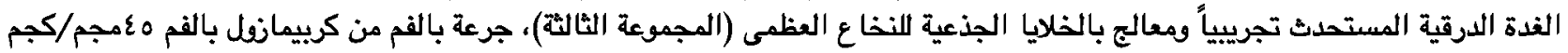

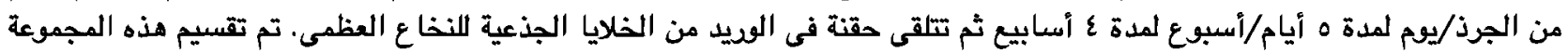

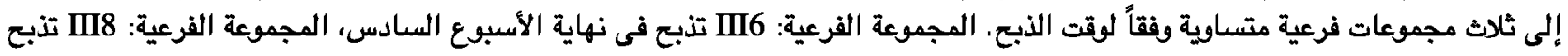

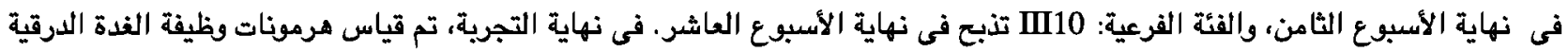

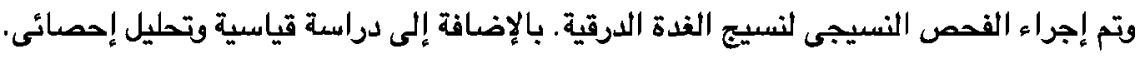

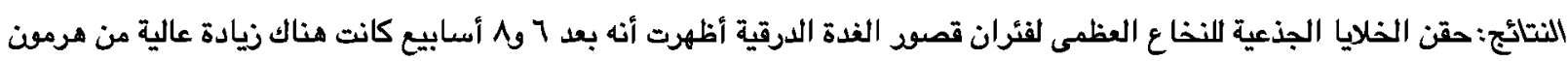

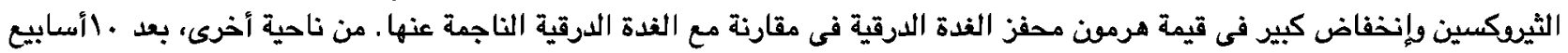

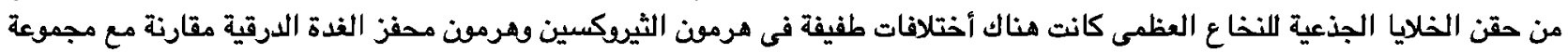

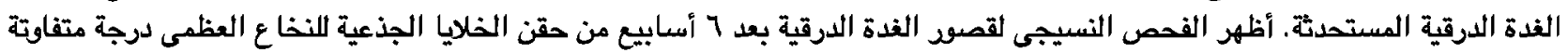

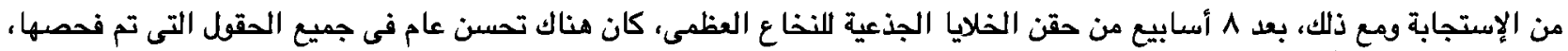

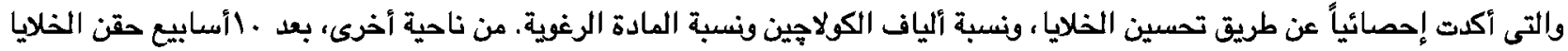

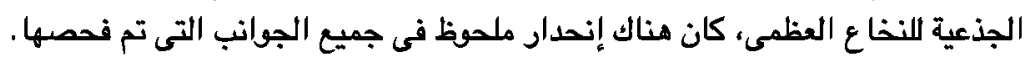

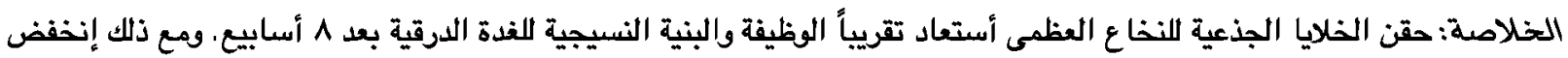

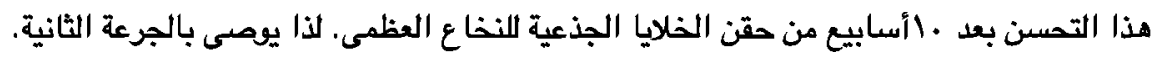

